\title{
Motivasi Petani Dalam Upaya Pemanfaatan Lahan Tidur di Kecamatan Peukan Bada Kabupaten Aceh Besar
}

(Motivation of Farmers in Efforts to Use Idle Land in Peukan Bada Districts Aceh Besar Regency)

\author{
Putri Sakinah $^{1}$, T. Makmur ${ }^{1}$, Azhar $^{1^{*}}$ \\ ${ }^{1}$ Program Studi Agribisnis, Fakultas Pertanian, Universitas Syiah Kuala
}

\begin{abstract}
Abstrak-Motivasi adalah suatu dorongan bagi perilaku seseorang untuk melakukan suatu usaha termasuk usaha dalam pemanfaatan lahan tidur. Lahan tidur merupakan lahan yang tidak diusahakan selama lebih dari dua tahun untuk kegiatan pertanian yang produktif. Suatu motivasi sangat diperlukan oleh seorang petani dalam mengupayakan pemanfaatan lahan tidur yang di pengaruhi oleh faktor ekonomi dan faktor sosial petani. Penelitian ini bertujuan untuk mengetahui tingkat motivasi petani dan faktor-faktor yang memotivasi petani dalam upaya pemanfaatan lahan tidur di Kecamatan Peukan Bada Kabupaten Aceh Besar. Hasil penelitian menunjukkan bahwa tingkat motivasi petani dalam upaya pemanfaatan lahan tidur tergolong sedang, artinya petani memiliki keinginan dan harapan yang tinggi akan tetapi petani memiliki keyakinan yang rendah untuk dapat memanfaatkan lahan tidur. Faktor-faktor yang memotivasi petani dalam upaya pemanfaatan lahan tidur yaitu faktor ekonomi yang terdiri dari modal dan pendapatan dan faktor sosial yang terdiri dari persepsi, sikap dan lingkungan.
\end{abstract}

Kata Kunci: Motivasi, Lahan Tidur, Pemanfaatan Lahan Tidur, Faktor Ekonomi dan Sosial

Abstract-Motivation is a boost for someone to do a business, including business in the utilization of idle land. Idle land is land that is not cultivated for more than two years for productive agricultural activities. A motivation is required by a farmer topursue the utilization of idle land that is affected by economic and social factors farmers. This study aims to determine the level of motivation of farmers and the factors that motivate farmersin efforts to use idle land in PeukanBada Districts,AcehBesarRegency.The results showed that the level of motivation of farmersin efforts to use idle landis classified, meaning that farmers have the desire and expectations were high but farmers have low confidence to be able to take advantage of idle land. Factors that motivate farmers in efforts to use idle land that is economic factors which consist of capital and income and social factors which consists of perception, attitude and environment.

Keywords: Motivation, Idle Land, Utilization of Idle Land, Economic and Social Factors

\section{PENDAHULUAN}

Lahan tidur adalah lahan pertanian yang sudah tidak diusahakan selama lebih dari dua tahun sehinggatidak menghasilkan suatu tanaman. Sebuah lahan pertanian yang tidak lagi produktif akan ditinggalkan sehingga menjadi lahan tidur. Lahan tidur biasanya hanya mengandalkan air dari hujan atau dapat disebut dengan teknik sistem tadah hujan (Basri, 2008).

Lahan tadah hujan yang lebih dari dua tahun tidak diusahakan menjadi lahan pertanian yang produktif dapat dijumpai di daerah Kecamatan Peukan BadaKabupaten Aceh Besar. Peukan Bada merupakan salah satu kecamatan yang memilikilahantidurterluas di Kabupaten Aceh Besar.Pada kecamatan ini terdapat lahan sawah tadah hujan yang dulunya pernah berproduksi namun sudah bertahun-tahun tidak diusahakan kembali untuk kegiatan pertanian yang produktif. Menurut informasidaripenyuluh Kecamatan Peukan Bada (2016), salah satu penyebab lahan tidak diusahakan yaitu dikarenakan lahan terkena dampak Tsunami yang terjadi pada tahun 2004. Artinya sudah 13 tahun lahan tersebut tidak diusahakan untuk 
kegiatan pertanian produktif. Adapun luas penggunaan lahan sawah di Kecamatan Peukan Bada Kabupaten Aceh Besar dapat dilihat pada tabel berikut ini:

Tabel 1. Luas Penggunaan Lahan Sawah di Kecamatan Peukan Bada Kabupaten Aceh Besar, Tahun 2015

\begin{tabular}{|c|c|c|c|c|c|c|}
\hline \multirow{3}{*}{ No } & \multirow{3}{*}{ Tahun } & \multicolumn{4}{|c|}{ Realisasi Dalam Satu Tahun } & \multirow{3}{*}{$\begin{array}{c}\text { Jumlah } \\
\text { (Ha) }\end{array}$} \\
\hline & & \multicolumn{2}{|c|}{ Ditanami padi } & \multicolumn{2}{|c|}{ Tidak ditanami padi } & \\
\hline & & $\begin{array}{c}1 \text { kali } \\
(\mathrm{Ha})\end{array}$ & $\begin{array}{c}2 \text { kali } \\
(\mathrm{Ha})\end{array}$ & $\begin{array}{c}\text { Ditanami } \\
\text { tanaman lain } \\
(\mathrm{Ha})\end{array}$ & $\begin{array}{c}\text { Tidak ditanami } \\
\text { tanaman lain } \\
(\mathrm{Ha})\end{array}$ & \\
\hline 1. & 2013 & 57,0 & 355,0 & 0,0 & 403,0 & 815,0 \\
\hline 2. & 2014 & 464,0 & 0,0 & 0,0 & 351,0 & 815,0 \\
\hline 3. & 2015 & 484,0 & 0,0 & 0,0 & 331,0 & 815,0 \\
\hline
\end{tabular}

Sumber: Dinas Pertanian Aceh, 2016.

Pada Tabel 1 terlihat bahwa di Kecamatan Peukan Bada terdapat lahan sawah yang tidak diusahakan untuk kegiatan pertanian yang produktif sehingga tidak menghasilkan suatu tanaman baik itu tanaman padi maupun tanaman pangan lainnya. Sehingga berdasarkan teori yang telah di kemukakan, lahan tersebut dapat dikatakan sebagai lahan tidur karena kondisi lahan yang tidak diusahakan untuk kegiatan pertanian yang produktif.

Di Kecamatan PeukanBada,beberapa lahan tidur telah dimanfaatkan untuk lahan pembangunan fisik dan beberapa lahan lainnya merupakan lahan terbengkalaiyang ditumbuhi oleh rumput-rumputan besar dan semak belukar. Secara teknis sebagian lahan tidur di kecamatan ini masih dapat diusahakan dan dikembangkan dengan melakukan pengelolaan lahan kembali. Namun, tetap saja hanya sebagian kecil dari petani di Kecamatan ini yang telah mengusahakan lahan tidur tersebut menjadi lahan yang produktif seperti dengan menanam tanaman cabai, bawang merah, kacang-kacangan, singkong dan umbi-umbian lainnya. Hal ini juga terlihat pada Tabel 1 bahwa luas lahan tidur setiap tahunnya semakin berkurang, yang artinya bahwa beberapa lahan telah dilakukannya pemanfaatan.

Motivasi merupakan pendorong utama terhadap perilaku seseorang untuk melakukan suatu usaha, termasuk usaha dalam upaya pemanfaatan lahan tidur. Motivasi yang ada dalam diri seseorang akan menentukan apakah seseorang akan mau, mampu, rajin dan kreatif untuk mengusahakan suatu usaha tersebut. Dorongan yang dapat membantu petani untuk mengusahakan suatu lahan dapat di peroleh dari faktor sosial dan ekonomi petani itu sendiri. Menurut Mardikanto (1996), motivasi seseorang akan dipengaruhi oleh status sosial ekonomi dan persepsi petani terhadap inovasi.

Adapun permasalahan dalam penelitian ini yaitubagaimana tingkat motivasi petani dan faktor-faktor yang memotivasi petani dalam upaya pemanfaatan lahan tidur di Kecamatan Peukan Bada Kabupaten Aceh Besar.

Tujuan penelitian ini adalah untuk mengetahui tingkat motivasi petani dan faktor-faktor yang memotivasi petani dalam upaya pemanfaatan lahan tidur di Kecamatan Peukan Bada Kabupaten Aceh Besar.

\section{METODOLOGI PENELITIAN}

Penelitian ini dilakukan di Kecamatan Peukan Bada Kabupaten Aceh Besar. Pemilihan lokasi dilakukan secara sengaja (Purposive Sampling), dengan pertimbangan letak geografis lahan (lahan pesisir dan bukan lahan pesisir), memiliki sumber air dan tidak memiliki sumber air serta persentase luas lahan tidur yang sudah dimanfaatkan dan belum dimanfaatkan menjadi lahan pertanian produktif.Sehingga, berdasarkan pertimbangan tersebut maka ditemukan lima desa yaitu desa Beuradeun, desa Lamgeu-Eu, desa Lam Manyang, desa Lam Badeuk dan desa Lam Rukam. Objek dalam penelitian ini adalah petani. Adapun ruang 
lingkup penelitian hanya terbatas pada data dan informasi mengenai tingkat motivasi petani serta faktor-faktor yang memotivasi petani dalam upaya pemanfaatan lahan tidur menjadi lahan pertanian yang produktif di Kecamatan Peukan Bada Kabupaten Aceh Besar.

Jenis data yang digunakan dalam penelitian ini yaitu data primer dan data sekunder. Dalam penelitian ini data primer diperoleh melalui pengamatan langsung dilapangan (observasi), pencatatan (dokumentasi) dan wawancara. Sedangkan data sekunder diperoleh melaluiDinas Pertanian, Badan Pusat Statistik (BPS) Aceh, Balai Penyuluhan Pertanian (BPP) Kecamatan Peukan Bada, perpustakaan serta jurnal penelitian.

Populasi dalam penelitian ini adalah petani.Adapun teknik pengambilan sampel yang digunakan dalam penelitian ini adalah Purposive Sampling kemudian dilanjutkan ke Snowball Sampling. Pertama-tama peneliti menggunakan teknik Purposive Sampling untuk menentukan responden yang akandijadikan sebagai informan penelitian yang dapat memenuhi kriteriapenelitian.Adapun pertimbangan dalam pengambilan sampel yaitu berdasarkan pada kemampuan sampel (informan) untuk memberikan informasi dengan selengkap mungkin kepada peneliti.Adapun kriteria responden dalam penelitian ini adalah seorang petani yang menetap dilokasi penelitian selamalebihdari 13 tahun, mengetahui penyebab adanya lahan tidur disekitar lingkungan petani serta petani yang sudah memanfaatkan lahan tidur menjadi lahan pertanian produktif.

Selanjutnya, untuk mendapatkan informasi data dan jumlah responden dalam penelitian ini, peneliti menggunakan teknik Snowball Sampling.Adapun jumlah responden yang didapatkan sebagai informan dalam penelitian ini adalah 16 responden. Hal ini dikarenakan peneliti sudah mencapai titik jenuh. Artinya, informasi yang diberikan oleh informan selanjutnya sama halnya dengan informasi yang diberikan oleh informan sebelumnya, begitu pula sampai seterusnya sampai informasi telah menjawab permasalahan penelitian (Hamid, 2010).

Metode analisis yang digunakan dalam penelitian ini adalah metode analisis deskriptif kualitatif dan kuantitatif yaitumendeskriptifkan kondisi-kondisi yang sekarang ini terjadi dan kemudian mengaitkan fakta tersebut dengan variabel-variabel yang ada pada landasan teori. Pembahasan dilakukan secara kualitatif yaitu menjelaskan berbagai kondisi dan situasi dari variabel yang digunakan tanpa menggunakan analisis statistik.

Untuk menjawab permasalahan pertama yaitu mengenai tingkat motivasi dalam upaya pemanfaatan lahan tidur, maka ada 3 langkah metode yang digunakan untuk menentukan tingkat motivasi dalam penelitian ini yaitu melalui kuisioner yang di susun dengan 3 indikator yaitu AIO (Aktivity, Interest, Opini), melalui metode wawancara (interview) dengan responden di lokasi penelitian. Melalui kuisioner yang diberikan kepada responden, dalam penelitian ini peneliti menggunakan metode skor (Scoring). Dalam penentuan skor akanmenggunakan pendekatan dengan skala Likert.

Tabel 2. Bobot Nilai Skor

\begin{tabular}{|c|l|c|}
\hline No. & \multicolumn{1}{|c|}{ Indikator Skor } & Nilai Skor \\
\hline 1. & Sangat Setuju (SS) & 5 \\
\hline 2. & Setuju (S) & 4 \\
\hline 3. & Ragu-Ragu (RG) & 3 \\
\hline 4. & Tidak Setuju (TS) & 2 \\
\hline 5. & Sangat Tidak Setuju (STS) & 1 \\
\hline
\end{tabular}

Sumber : Data Primer (diolah), 2016

Berdasarkan skala Likert yang digunakan pada kuisioner, setiap item jawaban dari pertanyaan akan diberi skor. Selanjutnya hasil skor dari seluruh pertanyaan pada kuisioner digolongkan menjadi dua kategori yaitu Memiliki Motivasi dan Tidak Memiliki Motivasi. 
Menurut Sugiono (2013) untuk menentukan kategori tersebut maka digunakan rumus penetapan skor sebagai berikut:

1. Jumlah Pertanyaan $=12$

2. Jumlah Pilihan $=5$

3. Skoring terendah $=1$

4. Skoring Tertinggi $=5$

Jumlah skor terendah $=$ skoring terendah $\mathrm{x}$ jumlah pertanyaan

$=1 \times 12=12=>(12 / 60 \times 100 \%)=20 \%$

$>$ Jumlah skor tertinggi $\quad=$ skoring tertinggi $\mathrm{x}$ jumlah pertanyaan

$=5 \times 12=60=>(60 / 60 \times 100 \%)=100 \%$

- Penentuan skoring pada kriteria objektif:

Rumus Umum :

$\mathrm{I}=\frac{R}{K} \ldots \ldots \ldots \ldots \ldots \ldots \ldots($ Hidayat, 2009$)$

Keterangan :

$\mathrm{I}=$ Interval

$\mathrm{R}=$ Range

$\mathrm{K}=$ Kategori

1. Range $(\mathrm{R})=$ Jumlah skor tertinggi- Jumlah skor terendah

$=100 \%-20 \%=80 \%$

2. Kategori $(\mathrm{K})=2$ kategori ( Memiliki Motivasi, dan Tidak Memiliki Motivasi)

3. Interval $(\mathrm{I})=\frac{80 \%}{2}=40 \%$

Kriteria penilaian $=$ Jumlah skor tertinggi - Interval

$$
=100 \%-40 \%=60 \%
$$

Sehingga:

a. Memiliki motivasi= Jika skor $>60 \%$

b. Tidak memiliki motivasi $=$ Jika skor $<60 \%$

Menurut Hidayat (2009), Kriteria motivasi dikategorikan menjadi :

1. Motivasi Kuat : $67 \%-100 \%$

2. Motivasi Sedang : $34 \%-66 \%$

3. Motivasi Lemah : $0 \%-33 \%$

Untuk menjawab permasalahan kedua yaitu mengenai faktor-faktor yang memotivasi petani dalam upaya pemanfaatan lahan tidur, maka faktor-faktor tersebut ditinjau dari segi faktor sosial dan faktor ekonomi. Peneliti melakukan wawancara secara mendalam (interview) sehingga hasil jawaban tersebut akan dibahas secara kualitatif kemudian akan dikaitkan dengan hasil penelitian terdahulu.

\section{KarakteristikResponden}

\section{HASIL DAN PEMBAHASAN}

Dalam berusaha tani, karakteristik petani memberi pengaruh terhadap kemampuan kerja petani dalam meningkatkan usaha taninya dan kecepatan berfikir saat mengambil keputusan. 
Karakteristik responden di dalam penelitian ini meliputi usia, tingkat pendidikan, jumlah tanggungan, pengalaman berusaha tani, pendapatan, luas lahan sawah yang produktif dan luas lahan sawah yang tidak produktif (lahan tidur).Adapun karakteristik responden yang didapatkan selama penelitian akan ditabulasikan dalam bentuk data seperti berikut.

Tabel 3.KarakteristikResponden

\begin{tabular}{|c|l|c|c|}
\hline No. & Karakteristik Responden & Satuan & Jumlah \\
\hline 1. & Usia & Tahun & $\geq 40$ \\
\hline 2. & Tingkat Pendidikan & Tahun & $\leq 3$ \\
\hline 3. & Jumlah Tanggungan & Orang & $10-19$ \\
\hline 4. & PengalamanBerusahatani & Tahun & $\leq 2.500 .000$ \\
\hline 5. & Pendapatan & Rupiah & $\geq 0,5$ \\
\hline 6. & Luas Lahan Sawah Produktif & Ha & $0,05-0,5$ \\
\hline 7. & Luas Lahan Tidur & Ha & \\
\hline
\end{tabular}

Sumber: Data Primer (diolah), 2016

Berdasarkan pada Tabel 3 dapat dilihat bahwa tingkat usia tertinggi adalah usia $\geq 40$ tahun yaitu sebanyak 12 responden atau 75 persen (\%). Usia sangat mempengaruhi petani untuk terus mengusahakan lahannya agar menjadi suatu lahan yang tetap produktif. Berdasarkan teori, usia petani di Kecamatan Peukan Bada tergolong usia produktif. Menurut hasil penelitian rata-rata usia petani yaitu 44 tahun.

Tingkat pendidikan petani adalah selama 12 tahun yaitu sebanyak 7 responden atau 43,75 persen (\%) dengan jenjang pendidikan yaitu tingkat SMA. Melalui pendidikan yang didapatkan, petani akan lebih mudah menerima inovasi-inovasi yang diberikan dengan memiliki pemahaman mengenai fungsi dan tata acara pemanfaatan lahan agar menjadi suatu lahan yang produktif.

Jumlah tanggungan rumah tangga petani adalah $\leq 3$ orang yaitu sebanyak 9 responden atau 56,25 persen (\%). Semakin banyak jumlah tanggungan dalam suatu keluarga maka semakin banyak pula biaya hidup yang harus diperoleh kepala keluarga agar kebutuhan keluarga dapat tercukupi. Semakin banyak biaya hidup yang harus didapatkan maka petani harus memiliki semangat untuk mendapatkan penghasilan dengan terus bekerja terutama dalam berusaha tani.

Responden dominan memperoleh pendapatan $\leq$ Rp. 2.500 .000 per bulan yaitu sebanyak 8 responden atau 50 persen (\%). Sumber pendapatan petani di Kecamatan Peukan Badayaitu merupakan pendapatan yang bersumber dari usaha tani padi dan non usaha tani. Pendapatan usaha tani padi yaitu jumlah pendapatan suami dan istri yang berusahatani pada lahan sawah, sedangkan pendapatan non usaha tani yaitu jumlah pendapatan suami, istri dan anak yang bekerja diluar sektor pertanian. Untuk menambah penghasilan keluarga, beberapa petani di Kecamatan Peukan Bada juga memiliki pekerjaan sampingan seperti wiraswasta atau non usaha tani dan petani akan mengalokasikan waktu kerjanya untuk mendapatkan penghasilan yang ditujukan pada kegiatan usaha tani dan non usaha tani.

Pengalaman responden dalam berusaha tani adalah selama 10 - 20 tahun yaitu sebanyak 9 responden atau 56,25 persen (\%). Rata-rata pengalaman petani dalam berusaha tani yaitu selama 13 tahun. Semakin lama pengalaman petani dalam berusaha tani, maka petani akan lebih banyak menghadapi kondisi baik dan kondisi buruk selama berusaha tani baik itu pada saat pencapaian keberhasilan maupun pada saat menghadapi kendala-kendala serta permasalahan yang pernah terjadi selama berusaha tani.

Luas lahan sawah produktif yang dimiliki petani adalah seluas $\geq 0,5$ ha atau $5000 \mathrm{~m}^{2}$ yaitu sebanyak 12 responden atau 75 persen (\%). Petani yang memiliki lahan yang lebih sempitsering tidak dapat menerapkan usahatani secara intensif karena harus bekerja pada 
pekerjaan lain diluar usahataninya dengan tujuan untuk memperoleh tambahan penghasilandemi memenuhi kebutuhan keluarganya. Oleh karena itu petani tidak selalu memiliki waktu yang luang untuk melakukanperubahan-perubahan usahataninya karena petani harus mengalokasikan waktu serta tenaganya pada pekerjaan usahataninya dan di luarusaha taninya (Mardikanto, 1996).

Di lokasi penelitian,jugamasih terdapat lahan bekas sawah yang tidak produktif (lahan tidur) yaitu seluas 0,05 ha- 0,5 ha dengan sebanyak 10 responden atau 62,5 persen (\%). Kondisi lahan tersebut sudah tidak lagi menghasilkan padiataupuntanamanproduktiflainnya. Artinya lahan tersebut telah menjadi lahan bekas sawah yang hingga kini tidak diupayakan atau diusahakan untuk kegiatan pertanian yang produktif. Menurut petani dilokasi penelitian (2016), lahan tersebut masih dapat diolah dan dimanfaatkan dengan menanam tanaman pangan lainnya. Hal ini juga didukung dengan pendapat Najiyanti, dkk (1999) yang menyatakan bahwa pemanfaatan lahan tidur dapat menjaga ketahanan pangan serta menjadi alternatif peningkatan penghasilan petani.

\section{Lahan Tidur}

Lahan-lahan yang belum dimanfaatkan untuk kegiatan pertanian produktif dapat dikategorikan sebagai lahan tidur (Karama dan Abdurrahman, 1994).Lahan tidur dalam penelitian ini adalah lahan bekas sawah yang belum dimanfaatkan atau diusahakan kembali khususnya untuk kegiatan pertanian dalam menghasilkan tanaman sehingga berdasarkan teori yang telah dikemukakan, maka lahan tersebut dapat dikatakan sebagai lahan tidur.

Dilokasi penelitian terdapat pula beberapa lahan tidur yang sudah dibersihkan dan dimanfaatkan untuk kegiatan pertanian. Menurut BPP Kecamatan Peukan Bada (2016), sebagian petani sudah mulai menanam tanaman produktif pada lahan tidur tersebut, seperti menanam kedelai, singkong, bawang merah dan cabai. Salah satu desa yang sebagian lahan tidurnya telah dimanfaatkan kembali menjadi lahan pertanian yang produktif yaitu Desa Lam Manyang. Adapun perubahan luas lahan berdasarkan kondisi lahan di Desa Lam Manyang dapat dilihat pada tabel berikut:

Tabel 4. Perubahan Luas Lahan Berdasarkan Kondisi Lahan di Desa Lam Manyang Kecamatan PeukanBadaKabupaten Aceh Besar, Tahun2015-2016

\begin{tabular}{|c|c|c|c|}
\hline No. & Kondisi Lahan & $\begin{array}{c}\text { Luas Lahan Tahun } \\
2015(\mathrm{Ha})\end{array}$ & $\begin{array}{c}\text { Luas Lahan Tahun } \\
2016(\mathrm{Ha})\end{array}$ \\
\hline 1. & Lahan yang diusahakan & 30 & 40 \\
\hline 2. & Lahan yang tidak diusahakan (lahan tidur) & 30 & 20 \\
\hline 3. & Lahan tidur yang sudah dimanfaatkan & - & 10 \\
\hline \multicolumn{2}{|c|}{ Jumlah } & 60 & 60 \\
\hline
\end{tabular}

Sumber: Data Primer (diolah), 2016

Pada Tabel 4 dapat dilihat bahwa petani di Desa Lam Manyang sudah memanfaatkan lahan tidur menjadi lahan pertanian yang produktif. Berdasarkan dari data BPS Aceh (2015), jumlah luas keseluruhan lahan sawah di Desa Lam Manyang yaitu seluas 60 ha, dimana seluas 30 ha adalah lahan sawah yang produktif dan seluas 30 ha adalah lahan yang tidak diusahakan atau disebut lahan tidur. Namun setelah dilakukan penelitian, saat ini luas lahan sawah yang produktif menjadi seluas 40 ha dan luas lahan tidur menjadi berkurang seluas 20 ha. Hal tersebut menunjukkan bahwa lahan tidur seluas 10 ha telah diusahakan kembali menjadi lahan pertanian yang produktif.

Sedangkan salah satu desa yang lahan tidurnya belum dapat dimanfaatkan yaitu berada di desa Lam Badeuk. Luas lahan sawah berdasarkan penggunaan lahan di Desa Lam Badeuk dapat dilihat pada tabel berikut: 
Tabel 5. Perubahan Luas Lahan Berdasarkan Kondisi Lahan di Desa Lam BadeukKecamatan PeukanBadaKabupaten Aceh Besar, Tahun 2015-2016

\begin{tabular}{|c|l|c|c|}
\hline No. & \multicolumn{1}{|c|}{ Kondisi Lahan } & $\begin{array}{c}\text { Luas Lahan } \\
\text { Tahun 2015 (Ha) }\end{array}$ & $\begin{array}{c}\text { Luas Lahan Tahun } \\
\text { 2016 (Ha) }\end{array}$ \\
\hline 1. & Lahan yang diusahakan & 25 & 22 \\
\hline 2. & Lahan yang tidak diusahakan (lahan tidur) & 20 & 23 \\
\hline 3. & $\begin{array}{l}\text { Lahan tidur yang sudah dibersihkan tetapi } \\
\text { belum dimanfaatkan }\end{array}$ & - & 8 \\
\hline \multicolumn{2}{|c|}{ Jumlah } & 45 & 45 \\
\hline
\end{tabular}

Sumber: Data Primer (diolah), 2016

Berdasarkan pada Tabel 5, luas keseluruhan lahan sawah di Desa Lam Badeuk pada tahun 2015 yaitu seluas 45 ha, dimana luas lahan yang diusahakan yaitu seluas 25 ha dan luas lahan tidur yaitu seluas 20 ha. Namun pada tahun 2016 setelah dilakukan penelitian di desa tersebut, saat ini luas lahan sawah yang produktif yaitu seluas 22 ha dan luas lahan tidur menjadi bertambah seluas 3 ha sehingga total luas lahan tidur di desa Lam Badeuk menjadi seluas 23 ha.

\section{Motivasi Petani Dalam Upaya Pemanfaatan Lahan Tidur}

Motivasi merupakan suatu dorongan yang sangat penting untuk dimiliki oleh petani agar petani tersebut mau dan mampu untuk terus melakukan kegiatan usahataninya dengan lebih baik dan optimal. Memanfaatkan lahan tentu sangatlah penting agar menunjang terwujudnya ketahanan pangan dengan mendapatkan hasil yang maksimal baik dari segi produksi maupun produktivitas. Berdasarkan dari hasil penelitian, motivasi petani untuk memanfaatkan lahan tidur masih tergolong sedang.

Pengukuran motivasi petani dalam penelitian ini adalah dengan melihat tiga indikator yaitu AIO (Aktivity, Interest and Opinion) melalui kuisioner yang diberikan kepada responden.Aktivitas (Aktivity) adalah tindakan yang telah dilakukan petani yang didasarkan pada keputusan petani untuk memanfaatkan lahan tidur. Beberapa petani di Kecamatan Peukan Bada sudah ada yang memulai memanfaatkan dan juga ada yang tidak mengusahakan lahan tidur tersebut. Minat (Interest) adalah daya tarik yang menjadi prioritas petani dalam memutuskan untuk memanfaatkan lahan tidur. Petani mempunyai keinginan dan harapan yang tinggi untuk dapat memanfaatkan lahan tersebut. Bertani merupakan kebiasaan petani di Kecamatan Peukan Bada untuk mendapatkan penghasilan sehari-hari demi mencukupi kebutuhan keluarganya meskipun lahan tidur yang sudah dimanfaatkan masih tergolong sedikit. Opini (Opinion) yaitu berupa pandangan atau tanggapan petani terhadap upaya pemanfaatan lahan tidur. Pandangan petani di Kecamatan Peukan Bada terhadap pemanfaatan lahan tidur berbeda-beda ada yang berpandangan positif dan juga ada yang negatif.Petani yang beranggapanpositifakanmengupayakanpemanfaatanlahantidur, begitu pula sebaliknya. Berikut ini dapat dilihat perolehan persentase skor motivasi petani.

Tabel 6. Persentase Motivasi Petani

\begin{tabular}{|c|c|c|c|c|c|c|c|c|c|}
\hline \multirow{2}{*}{ No. } & \multirow{2}{*}{ Variabel } & \multicolumn{4}{|c|}{ Indikator } & \multirow{2}{*}{$\begin{array}{c}\text { Jumlah } \\
\text { Skor }\end{array}$} & \multirow{2}{*}{ Rata-Rata } & \multirow{2}{*}{$\begin{array}{c}\text { Persentase } \\
(\%)\end{array}$} & \multirow{2}{*}{$\begin{array}{l}\text { Tingkat } \\
\text { Motivasi }\end{array}$} \\
\hline & & P1 & P2 & P3 & $\mathrm{P} 4$ & & & & \\
\hline 1. & Aktivitas & 39 & 38 & 62 & 62 & 201 & 16,7 & 335 & \\
\hline 2. & Minat & 66 & 66 & 57 & 39 & 228 & 19 & 380 & \\
\hline 3. & Opini & 44 & 55 & 55 & 49 & 203 & 16,9 & 338,3 & \\
\hline \multicolumn{6}{|c|}{ Jumlah } & 632 & 52,6 & $1.053,3$ & \\
\hline \multicolumn{6}{|c|}{ Rata-Rata } & 39,5 & 3,28 & 65,8 & Sedang \\
\hline
\end{tabular}

Sumber : Data Primer (diolah), 2016

Menurut Sugiono (2009) dalam penentuan kategori motivasi, jika skor $>60 \%$ maka petani memiliki motivasi. Jadi dapat disimpulkan bahwa petani di Kecamatan Peukan Bada 
memiliki motivasi untuk memanfaatkan lahan tidur karena 65,8\% $>60 \%$. Adapun kriteria tingkatmotivasi menurut Hidayat (2009) dikategorikan menjadi :

1. Motivasi Kuat : $67 \%-100 \%$

2. Motivasi Sedang : $34 \%-66 \%$

3. Motivasi Lemah : $0 \%-33 \%$

Sesuai dengan perolehan skor motivasi petani yaitu 65,8 \%, maka disimpulkan bahwa tingkat motivasi petani di Kecamatan Peukan Bada yaitu motivasi sedang karena perolehan skor 34\% - 66\%. Artinya bahwa ada beberapa hal yang menjadi pertimbangan petani di Kecamatan Peukan Bada mengusahakan atau tidak mengusahakan lahan tidur tersebut.

Adapun persentase responden dengan tingkat motivasi yang dimiliki dapat dilihat pada tabel berikut ini:

Tabel 7. Tingkat Motivasi Petani Dalam Upaya Pemanfaatan Lahan TidurDi Kecamatan Peukan Bada Tahun 2016

\begin{tabular}{|c|l|c|c|}
\hline No. & \multicolumn{1}{|c|}{ Kriteria Motivasi } & $\begin{array}{c}\text { Jumlah Petani } \\
\text { (Orang) }\end{array}$ & $\begin{array}{c}\text { Persentase } \\
(\%)\end{array}$ \\
\hline 1. & Kuat & 6 & 37,5 \\
\hline 2. & Sedang & 10 & 62,5 \\
\hline 3. & Lemah & - & - \\
\hline \multicolumn{2}{|c|}{ Jumlah } & 16 & 100 \\
\hline
\end{tabular}

Sumber: Data primer (diolah), 2016

Faktor-Faktor Yang Memotivasi Petani Dalam Upaya PemanfaatanLahan Tidur

Setelah dilakukan penelitian, ditemukan beberapa faktor yang menjadi dorongan petani untuk memanfaatkan lahan tidur menjadi lahan pertanian yang produktif. Ada dua aspek yang ditinjau yaitu faktor ekonomi dan faktor sosial. Kedua faktor ini adalah faktor terpenting yang memberi pengaruh kepada petani baik itu akan mempermudah atau menghambat petani dalam mencapai harapan-harapan yang ingin dicapai.

Berdasarkan hasil wawancara dengan petani responden selama penelitian, maka didapatkan persentase responden terhadap faktor-faktor yang memotivasi petani dalam upaya pemanfaatan lahan tidur di Kecamatan Peukan Bada Kabupaten Aceh Besar Tahun 2016 yang ditabulasikan dalam tabel berikut ini:

Tabel 8. Faktor-Faktor Yang Memotivasi Petani Dalam Upaya Pemanfaatan Lahan Tidur di Kecamatan Peukan Bada Kabupaten Aceh Besar, Tahun 2016

\begin{tabular}{|c|c|c|c|c|}
\hline \multirow{2}{*}{ No. } & $\begin{array}{c}\text { Aspek yang } \\
\text { Ditinjau }\end{array}$ & Variabel & $\begin{array}{c}\text { Jumlah Responden } \\
(\text { Petani })\end{array}$ & $\begin{array}{c}\text { Persentase } \\
(\%)\end{array}$ \\
\hline \multirow{2}{*}{1.} & \multirow{2}{*}{ Faktor Ekonomi } & Modal & 7 & 43,75 \\
\cline { 3 - 5 } & \multirow{3}{*}{2.} & Pendapatan & 7 & 43,75 \\
\cline { 3 - 5 } & \multirow{2}{*}{ Faktor Sosial } & Persepsi & 12 & 75 \\
\cline { 3 - 5 } & & Sikap & 10 & 62,5 \\
\cline { 3 - 5 } & & Lingkungan & 14 & 87.5 \\
\hline
\end{tabular}

Sumber : Data Primer (diolah), 2016

Berdasarkan hasil wawancara terdapat $43,75 \%$ responden yang telah memanfaatkan lahan tidur karena memiliki modal dan $56,25 \%$ responden yang belum memanfaatkan lahan tidur karena tidak memiliki modal. Oleh karena itu, modal sangat menentukan dorongan petani dalam mengupayakan pemanfaatan lahan tidur menjadi lahan pertanian yang produktif. Modal merupakan salah satu faktor yang menentukan petani mau berusaha tani atau tidak. Hasil penelitian menunjukkan bahwa petani mengalamikekurangan modal untuk mengolah lahan sehingga petani terkendala untuk mengusahakan lahan tidur.Lahan akan dapat dimanfaatkan jika petani memiliki modal yang cukup untuk pemanfaatan lahan tidur yang 
dimulai dari pembersihan lahan hingga menghasilkan tanamanproduktif. Oleh karena itu petani ataupun ahli waris harus memiliki modal yang besar untuk dapat memanfaatkan lahan tidur. Akan tetapi yang terjadi dilokasi penelitian, petani di Kecamatan Peukan Bada tidak memiliki modal yang cukup untuk mengusahakan lahan tersebut karena dana yang dimiliki hanya cukup untuk memenuhi kebutuhan keluarga.

Pendapatan merupakan salah satu faktor yang menentukan petani untuk berusaha tani. Sebagian besar petani di Kecamatan Peukan Bada memperoleh pendapatannya melalui hasil berusaha tani dan juga berasal dari pekerjaan sampingan (non pertanian). Dari hasil wawancara terdapat $43,75 \%$ responden yang memanfaatkan lahan tidur untuk mendapatkan penghasilan dari usaha tersebut. Motivasi yang dimiliki oleh seorang petani akan turut mempengaruhi hasil dan pendapatan yang diperoleh. Semakin besar lahan yang akan dikelola maka akan semakin besar pendapatan yang di peroleh dan akan semakin besar pula modal yang dibutuhkan. Pendapatan petani di Kecamatan Peukan Bada bersumber dari hasil pekerjaan baik dibidang pertanian dan dibidang non pertanian. Hasil pendapatan yang diperoleh melalui pekerjaan tersebut akan digunakan untuk memenuhi kebutuhan hidup keluarga petani.pendapatan yang diperoleh petani selama ini hanya dapat memenuhi kebutuhan hidup keluarganya, artinya tidak dapat digunakan untuk dana pemanfaatan lahan tidur. Oleh karena itu untuk menambah pendapatan, petani mau menerima bantuan dari pemerintah yaitu berupa bantuan bibit tanaman bawang merah dan cabai sehingga mereka bisa mengembangkan usaha tanaman tersebut pada lahan tidur.

Persepsi diartikan sebagai tanggapan seseorang pada suatu hal yang dianggap penting atau menimbulkan keresahan dalam kehidupan sosial masyarakat. Dari hasil wawancara dengan petani responden, terdapat $75 \%$ responden yang beranggapan bahwa lahan tidur yang dimiliki masih dapat diusahakan menjadi lahan pertanian yang produktif. Oleh karena itu persepsi petani dapat mendorong petani dalam upaya pemanfaatan lahan tidur menjadi lahan pertanian produktif. Persepsi petani di Kecamatan Peukan Bada terhadap upaya pemanfaatan lahan tidur yaitu positif. Petani percaya bahwa lahan tidur yang berada di lingkungan mereka dapat dimanfaatkan kembali untuk kegiatan pertanian yang produktif guna dapat meningkatkan kesejahteraan perekonomian masyarakat petani di Kecamatan Peukan Bada. Jika persepsi petani positif terhadap upaya pemanfaatan lahan tidur maka akan mendorong petani bertindak dalam pemanfaatan lahan tidur.

Sikap adalah kesiapan atau kesediaan petani untuk bertindak yang merupakan salah satu faktor yang mendorong petani dalam memanfaatkan lahan tidur menjadi lahan pertanian produktif. Berdasarkan hasil wawancara, terdapat $62,5 \%$ responden yang memiliki kesiapan dan kesediaan untuk mengupayakan pemanfaatan lahan tidur menjadi lahan pertanian yang produktif.Sikap petani dalam penelitian ini adalah petani meyakini bahwa ilmu yang ada di dalam dirinya dan informasi-informasi yang diterima mengenai inovasi-inovasi dapat memberikan manfaat dan keuntungan apabila ilmu itu dapat di terapkan dalam kehidupan sehari-hari. Selain itu sikap petani yang semangat dalam mengembangkan usaha tani bawang merah dan cabai sehingga melalui usaha tersebut mereka mendapatkan hasil yang dapat menambah pendapatan dalam memenuhi kebutuhan petani dan keluarga petani. Akan tetapi masih terdapat sebagian petani yang tidak mengupayakan pemanfaatan lahan tidur dikarenakan kebiasaan petani yang malas untuk bergerak seperti kebiasaan mereka yang bekerja diluar usaha non pertanian serta kebiasaan masyarakat yang hanya duduk diam di warung kopi.

Lingkungan juga merupakan salah satu faktor pendukung yang kuat bagi petani agar mengolah lahan tidur menjadi lahan pertanian produktif. Lingkungan di dalam penelitian ini terbagi atas dua yaitu lingkungan alam serta lingkungan masyarakat petani sekitar. Maslow (1994) mengungkapkan bahwa motivasi manusia tidak akan terlepas dari lingkungan 
sekitarnya baik dari situasi dan dengan orang lain.Dari hasil wawancara dengan petani responden, terdapat $87,5 \%$ responden yang telah mengupayakan pemanfaatan lahan tidur menjadi lahan pertanian yang produktif karena adanya kerja sama dalam lingkungan masyarakat petani. Oleh karena itu lingkungan sangat mempengaruhi dorongan bagi petani dalam upaya pemanfaatan lahan tidur.

Lingkungan alam dalam penelitian ini yaitu lahan yang berada di lokasi penelitian masih sangat layak untuk dikembangkan dan dijadikan lahan pertanian produktif baik dilihat dari segi dataran, $\mathrm{Ph}$ tanah dan suhu, sehingga dapat mendorong petani untuk mengelola lahan tidur di lokasi penelitian. Menurut hasil wawancara dengan petani, hasil produksi tanaman yang sudah dimanfaatkan pada lahan tidur tersebut juga memberikan hasil produksi yang baik. Namun lingkungan alam lain juga menghambat petani dalam bertindak yaitu tidak adanya sumber air di lokasi penelitian sehingga menjadi penghambat petani dalam berusahatani. Dikarenakan air yang tidak dapat terjangkau menyebabkan beberapa petani terkendala dan tidak yakin untuk dapat mengusahakan semua lahan tidur di Kecamatan Peukan Bada menjadi lahan pertanian produktif.

Selain lingkungan alam maka petani pun mendapatkan dorongan yang tinggi dari masyarakat petani lainnya untuk bersama-sama mengelola lahan tidur menjadi lahan pertanian produktif. Hal ini terjalin karena adanya sebagian petani yang sudah mengelola lahan tersebut maka petani lain pun ikut tergerak untuk memanfaatkan lahan tidur yang berada di sekitar nya dengan ketentuan dan syarat yang telah di tetapkan oleh gampong. Petani juga mendapatkan kenyamanan yaitu hubungan antar petani yang harmonis, meskipun terdapat beberapa konflik antar sesama petani. Akan tetapi hal tersebut dapat terselesaikan dengan rasa kekeluargaan meskipun konflik sosial yang terjadi dalam masyarakat petani juga menyebabkan beberapa petani di Kecamatan Peukan Bada malas dan tidak yakin untuk bisa melanjutkan usaha taninya.

Adapun persentase $(\%)$ responden terhadap faktor-faktor yang memotivasi petani dalam upaya pemanfaatan lahan tidur di Kecamatan Peukan Bada baik dari segi faktor ekonomi dan faktor sosial dapat dilihat melalui grafik berikut :

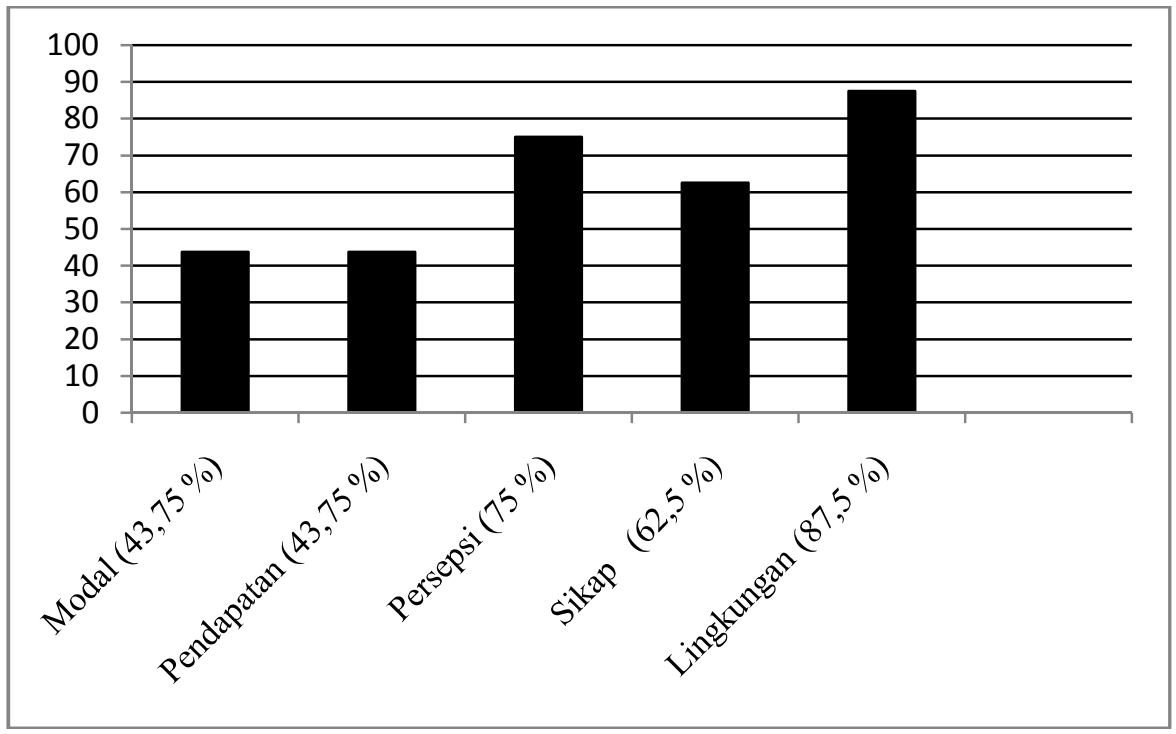

\section{Gambar 1.Grafik Persentase Responden Terhadap Faktor-Faktor Yang Memotivasi Petani Dalam Upaya Pemanfaatan Lahan Tidur di Kecamatan Peukan Bada Kabupaten Aceh Besar Tahun 2016.}


Pada grafik diatas dapat dilihat bahwa persentase responden tertinggi adalah faktor lingkungan yaitu sebanyak 87,5 persen $(\%)$. Faktor lingkungan sangat mendukung petani untuk memanfaatkan lahan tidur menjadi lahan pertanian yang produktif seperti lingkungan masyarakat yang harmonis dan saling bekerjasama dalam membersihkan lahan tidur agar dapat dimanfaatkan untuk kegiatan pertanian yang produktif. Kemudian diikuti dengan faktor persepsi yaitu sebanyak 75 persen (\%). Persepsi petani sangat mempengaruhi petani untuk memanfaatkan lahan tidur menjadi lahan pertanian yang produktif. Dengan persepsi yang positif terhadap lahan tidur maka petani mau mengupayakan pemanfaatan lahan tidur.

\section{KESIMPULAN DAN SARAN}

Petani di Kecamatan Peukan Bada memiliki motivasi dalam upaya pemanfaatan lahan tidur menjadi lahan pertanian yang produktif dengan tingkat motivasi yang dimiliki petani yaitu motivasi sedang.Faktor-faktor yang memotivasi petani dalam upaya pemanfaatan lahan tidur menjadi lahan pertanian yang produktif yaitu terdiri dari dua faktor yaitu faktor ekonomi dan faktor sosial. Faktor ekonomi terdiri dari modal dan pendapatan petani. Sedangkan faktor sosial terdiri dari persepsi, sikap dan lingkungan.

Diharapkan kelompok tani di Kecamatan Peukan Bada lebih diaktifkan lagi untuk meningkatkan motivasi petani dalam upaya pemanfaatan lahan tidur dan diharapkan kepada pemerintah untuk mempermudah bantuan dan mengintensifkan program optimasi lahan dalam upaya pemanfaatan lahan tidur guna meningkatkan motivasi petani untuk berusahatani dan menghasilkan produk pertanian khususnya tanaman pangan yang memberi nilai ekonomi dan sosial petani.

\section{DAFTAR PUSTAKA}

Basri Jumin, Hasan. 2008. Dasar-dasar Agronomi. PT Raja Grafindo Jaya. Jakarta.

Hamid, P. 2010. Metode Penelitian Kualitatif. UMM Press. Malang.

Karama, A. S. dan A. Abdurrahman. 1994. Optimasi Pemanfaatan Sumberdaya Lahan Berwawasan Lingkungan. Prosiding Simposium Penelitian Tanaman Pangan III Buku I. Puslitbangtan. Deptan.

Mardikanto, T. 1996. Dasar-Dasar Komunikasi Pembangunan. PT. Balai Pustaka (Persero). Jakarta.

Maslow, A.H. 1994. Motivasi dan Kepribadian: Teori Motivasi dengan Hierarki Kebutuhan Manusia. PT. Pustaka Binaman Pressindo. Jakarta.

Najiyanti, Sri dan Danarti.1999. Pemanfaatan Lahan Tidur Untuk Tanaman Pangan. Penebar Swadaya. Jakarta.

Sugiono. 2013. Metode Penelitian Kuantitatif, Kualitatif dan R\&D. Bandung: Alfabeta. 
Wowiling, R. E. 2014. Analisis Sosial Ekonomi Masyarakat Terhadap Bertambahnya Lahan Tidur Di Desa Taraitak Kecamatan Langowan. Skripsi. Fakultas Pertanian. Universitas Sam Ratulangi. Manado. 